\title{
Paleoecology of Easter Island: evidence and uncertainties
}

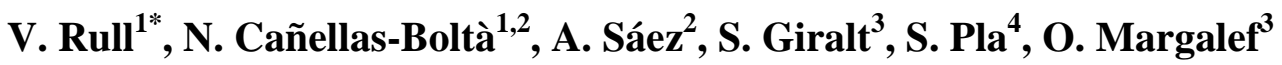

${ }^{1}$ Laboratory of Palynology and Paleoecology, Botanic Institute of Barcelona (CSICICUB), Passeig del Migdia s/n (Montjuïc), 08038 Barcelona, Spain.

${ }^{2}$ Department of Stratigraphy, Paleontology and Marine Geosciences, Faculty of Geology, University of Barcelona, 08028 Barcelona, Spain.

${ }^{3}$ Department of Sedimentary Geology, Institute of Earth Sciences “Jaume Almera” (CSIC), C. Lluís Solé Sabarís s/n, 08028 Barcelona, Spain

${ }^{4}$ Limnology Group, Center for Advanced Studies of Blanes (CSIC), C. Accés Cala St. Francesc 14, Blanes, 17300 Girona, Spain

*Corresponding author. Tel. +34 93 2890611; fax +34 932890614.

E-mail address: vrull@ibb.csic.es (V. Rull)

Keywords: Rapa Nui, palynology, Pleistocene, Holocene, palms, deforestation, islands, Pacific Ocean 


\section{Abstract}

The existence of palm-dominated forests covering the island since the last glaciation and the recent deforestation by humans are paradigmatic in Easter Island's paleoecological reconstructions. The timing and mode of the deforestation are controversial, but there is general agreement that it actually occurred, and it is often given as an example of a human-induced environmental catastrophe with philosophical implications for the future of the whole planet. To evaluate whether this is the only well-supported hypothesis or if there might be other scenarios compatible with the paleoecological data, this paper reviews all the available evidence on past vegetation changes on Easter Island. The discussion is centered on three main points: 1) the alleged nature and extension of the former forests, 2) the taxonomic identity of the dominant palms, and 3) the nature of the recent ecological changes leading to a treeless island. The potential causes of the assumed deforestation are beyond the scope of this study. Concerning the first point, palynological and anthracological results obtained so far are not only compatible with a forested island, but also with other scenarios, for example a mosaic vegetation pattern with forests restricted to sites with a high freshwater table (gallery forests), which are mostly around the permanent lakes and along the coasts. With regard to palm identity, some extant species have been proposed as potential candidates, but the palms that dominated these forests seem to have become extinct and their identity remains unknown. The existence of a sedimentary hiatus around the dates of forest decline complicates the picture and reinforce the possibility of climatic changes. It is concluded that the hypothesis of a previously forested island has yet to be demonstrated. Therefore, the recent ecological disaster, human-induced or not, is still speculative. Several types of future studies are proposed for a better understanding of Easter Island's ecological history, including: modern analog studies from similar situations, pollen dispersal modeling, high-resolution multi-proxy studies along the cores obtained so far, more coring campaigns in the search for older sediments, and DNA and isotopic analyses of plant remains for taxonomic identification purposes. 


\section{Introduction}

Easter Island (or Rapa Nui) has been the object of an intense debate about the causes of an assumed ecological catastrophe that occurred in historical times dealing to a cultural collapse, and which is often used as a model for the potential future consequences of the over-exploitation of natural resources (Rainbird, 2002; Flenley and Bahn, 2003;

Diamond, 2005; Nagarajan, 2006). This case transcended the scientific community and reached the popular literature and mass media, becoming with time a more or less well established example of how humans can destroy their own habitat and lead themselves to a societal breakdown.

The whole story began with an archaeological expedition to the island that reported the occurrence of an unknown, palm-like pollen in ancient sediments (Heyerdahl and Ferdom, 1961), a surprising fact considering that the island is today totally covered by grasslands and the only palms present are of recent introduction (Zizka, 1991). Further pollen analyses of lake sediment cores from three volcanic craters showed a clear replacement of palm-dominated assemblages by grass-dominated ones, which has been interpreted in terms of deforestation by indigenous people (Flenley and King, 1984;

Flenley et al., 1991). This generated a series of ecological and anthropological inferences that led to a still standing controversy about the role of humans (either natives or Europeans), the climate and even rats in the island's deforestation (HunterAnderson, 1998; Flenley and Bahn, 2007a, b; Hunt and Lipo, 2007; Flenley et al., 2007).

So far, the mainstream of the debate has been centered on the causes and consequences of the ecological disaster, as designated by Flenley (1993), whereas other important aspects of the problem have been taken for granted by most researchers with little or no discussion. These are: that the island was covered by forests prior to human arrival, and that the deforestation was likely caused by humans. These issues are at the core of the problem as they deal with the evidence itself and its interpretation, which is the starting point for any further discussion. The magnitude of ecological and cultural inferences about Easter Island's history contrasts with the limited number of cores studied, their fragmentary nature and the low resolution of the analyses, the few proxies used (mostly pollen), and the existence of a sedimentary hiatus within which important information 
about the environmental shift is still hidden (Mann et al., 2008). At present, studies about the paleoecology of the island seem to have spring up again and new cores have been obtained and are being analyzed (Gossen, 2007; Azizi and Flenley, 2008; Mann et al., 2008; Sáez et al., 2009). We consider it appropriate to accurately review the existing evidence at this point, to provide a neutral perspective on the proposals erected so far.

This paper reviews the raw evidence available for past vegetation and vegetation change on Easter Island, with the aim of disentangling the well-supported hypotheses on island's paleoecology from those that still need further work to be confirmed or rejected. It should be emphasized that the proposed cultural collapse itself and its possible causes will not be objects of our analysis; we only aim to evaluate the paleoecological evidence commonly associated with it. Hunt and Lipo (2007) and Flenley et al. (2007) discussed several controversial dating and archaeological aspects, and Hunter-Anderson (1998) did a general review of the problem from an anthropological perspective. Here, we concentrate on the evidence for vegetation change and its implications. The review begins with a classification and a brief explanation of the hypotheses proposed so far on the potential causes of the assumed deforestation (section 2). This section is necessary to understand further discussions about the evidences supporting the different views of Easter Island paleoecology. The second part (section 3) is an overview of the island today, including the locations of the sites mentioned in the text. The next part (section 4) examines the evidence for the existence and taxonomic composition of the forests predating human establishment, as well as their late Pleistocene and Holocene history. Then, the key vegetation change, i.e., the replacement of forests by grasslands, is analyzed in some detail (section 5). Finally, new studies oriented towards testing the still unsolved questions, as well as a new hypothesis, are proposed (section 6). This paper is also intended as a "hygienic" introduction to further paleoecological studies on new cores obtained from peat and lake sediments on Easter Island (Sáez et al., 2009).

\section{Background and current hypotheses}

The existing hypotheses regarding Easter Island's prehistoric deforestation can be broadly classified into two categories, namely anthropic and climatic. Among the anthropic hypotheses, we can distinguish between those dealing with direct and indirect 
consequences of human activities. Active forest clearing, either by natives or Europeans, are considered direct actions, and rat consumption falls within the indirect category. Proposals within this group are commonly based on paleoecological and/or archaeological evidence and will be discussed here. Climatic hypotheses, on the contrary, are still speculative, and there is no any evidence independent from the palynological records to either support them or not. These proposals are briefly outlined at following.

According to the above-mentioned palynological studies, the island was forested before the arrival of humans, which possibly occurred around AD 800 (Vargas et al., 2006) or AD 1200 (Hunt and Lipo, 2006). It has been suggested that during the late Pleistocene and most of the Holocene, prior to human establishment, the forests were dominated by palms (Flenley and King, 1984; Flenley et al. 1991). Coupled stratigraphic variations in the pollen of these forest elements and of grasses allowed these authors to infer a cool and dry phase between 26 and $12{ }^{14} \mathrm{C}$ kyr BP, followed by an increase in precipitation and an expansion of forests that persisted throughout the Holocene until the recent deforestation. A recent, more detailed pollen analysis of sediments representing the Last Glacial Maximum (LGM) used the alternation of palm and grass pollen to infer a phase cooler and probably drier than the present (Azizi and Flenley, 2008). Minimum values of palm pollen coinciding with maximum grass values around 22 and $17{ }^{14} \mathrm{C}$ kyr BP were interpreted in terms of the coldest and driest phase of this interval.

Depending on the authors, the deforestation took place either around AD 1000-1200 (Flenley and Bahn, 2007b; Mann et al., 2008) or some 600 years later (Hunt, 2006; Hunt and Lipo, 2007). The more popular hypothesis is that indigenous Rapa Nui people were responsible for the forest demise, as they used the wood for a variety of purposes, including the transportation of their characteristic stone statues or moais (Gurley and Liller, 1997; Grau, 2001). Other authors claim an important role for rats -mainly the European introduced Rattus exulans- in the disappearance of the palms, by active fruit eating (Hunt, 2006). This proposal is based on the abundance of rat bones and skeletons in archaeological excavations and the discovery of many palm fruits with signs of gnawing and removal of the interior nuts (Hunt, 2007). An “ecocide” caused by Europeans after their arrival in the $18^{\text {th }}$ century has also been suggested (Rainbird, 2002; Peiser, 2005), but no evidence has been provided. Another group of hypotheses center 
around natural climatic changes as causal agents for both the vegetation and the cultural shift. This view was introduced by McCall (1993), who speculated about the possibility of a dramatic climate shift linked to the Little Ice Age (LIA). Further proposals in the same vein cite the potential influence of ENSO variability (Orliac and Orliac, 1998; Orliac, 2000; Nunn, 2000; Nunn and Britton, 2001) or deny this possibility (MacIntyre, 2001; Genz and Hunt, 2003) based on reasonable speculations or climatic records of the last 50 years, respectively. Similarly, Hunter-Anderson (1998) proposed a geo-climatic model to explain the disappearance of the palms in which mid to late-Holocene climatic instability would have played a major role. According to this author, humans (Polynesians) arrived on the island during a "climatic optimum”, from a human point of view, occurring between about 1200 and $600 \mathrm{BP}$, at which time the island was already grass-covered with only a few trees and shrubs growing on protected sites. Recently, Mann et al. (2008) and Sáez et al. (2009), using pollen analysis and lake level reconstructions, respectively, proposed the existence of a mid-Holocene dry period characterized by a sedimentary hiatus. According to Mann et al. (2008), this period was followed by forest clearance by humans. A combination of climatic and anthropogenic causes for deforestation has been also proposed by Louwagie et al. (2006).

\section{Present-day overview and study sites}

\subsection{Geography, hydrology and climate}

Easter Island is one of the most isolated places on Earth. It is located in the Pacific Ocean $\left(27^{\circ} 07^{\prime} \mathrm{S}-109^{\circ} 22^{\prime} \mathrm{W}\right)$ at about $3700 \mathrm{~km}$ of the Chilean coast and $2030 \mathrm{~km}$ from the nearest oceanic island (Pitcairn) (Fig. 1). The indigenous name for the island is Rapa Nui, and the inhabitants are commonly called Rapanuis (McLaughlin, 2007). The island originated with the fusion of three volcanic cones (Maunga Terevaka, Rano Kao and Poike), which formed a roughly triangular land mass of nearly $164 \mathrm{~km}^{2}$. In addition to these major volcanoes, the island is spiked by around 70 other minor satellite cones. The island has a triangular shape and is dominated by the summit of the Terevaka volcano (511 $\mathrm{m}$ asl), which has steep slopes at the north and more gentle slopes in the other directions, where most inhabited sites of the island are located (Fig. 1). 
Hydrologically, the island is characterized by an absence of permanent surficial water currents due to the high permeability of volcanic rocks and the existence of abundant fractures and lava tubes (Herrera and Custodio, 2008). Fresh water accumulates on top of a groundwater system in which salinity increases with depth due to the penetration of seawater from below (Fig. 2). The subsurficial freshwater lens is used for human consumption through the boring of wells (Herrera and Custodio, 2008). Another source of freshwater is the bog inside the Rano Aroi crater, which outflows through a small creek that infiltrates downstream for about $400 \mathrm{~m}$. The chemical composition of the Aroi water is similar to that of the groundwater, suggesting that it may represent the discharge of a more or less stable groundwater body that is perched there, or that is the result of a highly saturated zone (if there is a volcanic core of low permeability volcanics there). Since it is near the top, it is easily subjected to seasonal variations and even desiccation (Herrera and Custodio, 2008). On the other hand, the Raraku and Kao craters hold permanent lakes that are fed solely by precipitation and which are closed basins hydrologically disconnected from the main groundwater system by impermeable lacustrine sediments.

The climate of Easter Island is subtropical, with an average annual temperature of $21^{\circ} \mathrm{C}$ and a range of average monthly temperatures between $18{ }^{\circ} \mathrm{C}$ in August and $24^{\circ} \mathrm{C}$ in January (Mann et al., 2008). The total annual precipitation is highly variable, ranging between 500 and $1800 \mathrm{~mm}$ (average $1130 \mathrm{~mm}$ ); the maximum rainfall occurs from April to June, and the driest moth is October with $70 \mathrm{~mm}$ (Azizi and Flenley, 2008). The influence of ENSO variability on the island's climate is still unclear (MacIntyre, 2001; Genz and Hunt, 2003; Muccianore and Dunbar, 2003).

\subsection{Flora and vegetation}

The island is covered by meadows (90\%), forests (5\%), shrublands (4\%), and pioneer and urban vegetation (1\%) (Etienne et al., 1982). The meadows are dominated by grasses, mainly Sporobolus indicus and Paspalum scrobiculatum, with Axonopus paschalis a local dominant in the highest sectors of the Maunga Terevaka. The more common forests are recent plantations of Eucalyptus spp. (Myrtaceae) and Dodonea viscosa (Sapindaceae), both introduced, and the native Thespesia populnea (Malvaceae). Shrublands are largely dominated by the invader Psidium guajava 
(Myrtaceae), also introduced. Inside the major craters, the only places of the island with permanent fresh water, aquatic vegetation dominated by Scirpus californicus (Cyperaceae) and Polygonum acuminatum (Polygonaceae) exists. According to Zizka (1991), the angiosperm flora of the island is composed of 179 species, of which 30 (16.8\%) are autochthonous and 141 (78.8\%) are introduced. The remaining $8(0.4 \%)$ are of uncertain origin. Among the introduced species, 67 are considered to be well established (naturalized) and 74 have been observed only rarely (ephemerophytes). Globally, the families with more species are Asteraceae (19) and Fabaceae (18), but if we consider only the autochthonous flora, Poaceae (9) and Cyperaceae (5) are the most represented (Zizka, 1991). Species endemic to Easter Island are: Axonopus paschalis (Poaceae), Danthonia paschalis (Poaceae), Sophora toromiro (Fabaceae), and probably Paspalum fosterianum (Poaceae). Given the isolation of Easter Island, the ways in which the autochthonous species reached the island are of special significance. Interestingly, none of the autochthonous angiosperms has potential for wind dispersal, the main mechanisms being transport by birds (75\%) and drift through seawater (25\%) (Carlquist, 1967; 1974). From a conservation point of view, it is especially interesting that Sophora toromiro is now extinct in the wild and is currently maintained under cultivation in the island and in several botanical gardens elsewhere (Maunder et al., 2000). The flora and vegetation of Easter Island are seriously threatened by human activities, livestock (notably horses), and the introduction of aggressive invader species. It has been proposed that the inner slopes of Rano Kao would be an excellent site for the conservation of the local flora (Zizka, 1993).

\subsection{Study sites and proxies}

The evidence for past vegetation change comes primarily from palynological and archaeological surveys. The locations discussed in this paper are depicted in Figure 1. Pollen analyses are mostly based on the sediments inside the three volcanic craters (Fig. 3). Two of them -Rano Raraku ( 400 m diameter, $2 \mathrm{~m}$ of maximum water depth and 75 m elevation) and Rano Kao ( 1000 m diameter, 8 m of maximum water depth and 110 m elevation)- contain lakes, and the third -Rano Aroi ( 150 m diameter and $430 \mathrm{~m}$ elevation)- contains a peat bog (Flenley and King, 1984; Flenley et al., 1991; Butler and Flenley, 2001; Peteet et al., 2003; Gossen, 2007; Azizi and Flenley, 2008; Mann et al, 2008). Microscopic charcoal, a proxy for fire, was reported in Rano Aroi, Rano Raraku 
and Rano Kao (Flenley et al., 1991; Mann et al., 2008). A paleolimnological study based on zooplankton remains and diatoms is also available for Rano Raraku (Dumont et al., 1998). The main archaeological evidence, in the context of the present review, consists of carbonized macroscopic wood fragments found in Hanga Hoonu, Orongo, Ahu Akahanga and Hanga te Pahu (Arnold et al., 1990; Orliac and Orliac,1998; Orliac, 2000). More charcoal remains from wood associated with root casts were found south of the Poike Peninsula (Flenley, 1993; Mieth and Bork, 2003, 2010; Stevenson et al., 2006). Sometimes, charcoal fragments are associated with phytoliths and pollen, as is the case in Te Niu, Ahu Hekii and the coasts of La Pérouse Bay (Cummings, 1998; Horrocks and Wozniak, 2008). The only physico-chemical proxies analyzed so far are major cations (Fe, Al, Na, K, Mn, Ca and Mg) in Rano Raraku, Rano Aroi and Rano Kao (Flenley et al., 1991) and magnetic susceptibility (only in Rano Kao) (Gossen, 2007).

\section{The ancient forests}

\subsection{The evidence and its current interpretation}

According to Butler and Flenley (2001), "the island was forested for many thousands of years before human impact.” The oldest pollen records interpreted in terms of a forested island extend back to $\sim 35-37{ }^{14} \mathrm{C}$ kyr BP and were obtained in Rano Raraku and Rano Aroi. The pollen diagram of the first site is of millennial resolution (average betweensample intervals of $\sim 1100$ years), whereas that of the second site is multicentennial (one sample each 580 years in average). In Rano Raraku core RRA3, Palmae pollen dominates the whole diagram from $\sim 35{ }^{14} \mathrm{C}$ kyr BP until the uppermost meter. Typical percentages are $40-70 \%$ of total pollen, with a minor decline to $20 \%$ around $\sim 28{ }^{14} \mathrm{C}$ kyr

BP. In the lowermost part of the diagram, between around 35 to $28{ }^{14} \mathrm{C} \mathrm{kyr} \mathrm{BP}$, the three samples analyzed indicated total Palmae dominance with scattered occurrences of other elements. This was interpreted in terms of a forest dominated by palms with a shrubby understory of Sophora, Asteraceae (Tubuliflorae), Triumfetta, Urticaceae/Moraceae and Macaranga (Flenley et al., 1991). The same forest, but in a more open condition, was assumed to exist between $\sim 28$ and $12{ }^{14} \mathrm{C}$ kyr BP. Openness was suggested by a slight decline in palm pollen, and an increase in that of shrubs and Poaceae. Between 12 and $1.2{ }^{14} \mathrm{C}$ kyr BP, palm forests like those of the first phase would have recovered, but this 
time with a lower diversity, as reflected in the rarity or absence of some of the shrub elements. Grasses were also scarce.

Additional data on the potential palm forests were provided by a further core obtained in Rano Raraku (RRA5) covering between 28 and $11{ }^{14} \mathrm{C}$ kyr BP (Azizi and Flenley, 2008). In this case, the resolution was 680 years per sample interval. The pollen diagram of this section, which includes the LGM, is commonly dominated by Palmae (40-80\%), with Poaceae, Asteraceae (Tubuliflorae), Sophora and Poaceae as subdominants. The interpretation, in terms of the dominant vegetation, is basically the same as in the former RRA3 core, but this time with emphasis on Sophora, Palmae and Triumfetta as the main tree elements (Azizi and Flenley, 2008). The Holocene vegetation is represented in another Rano Raraku core (\#1) covering the last $\sim 6$ cal kyr BP with multidecadal resolution ( 280 years per sample interval). In this case, prior to the "deforestation," the pollen palm dominance approaches $100 \%$ in all samples, and apart from it, only Cyperaceae pollen is commonly present (Mann et al., 2008). An explicit reconstruction of the potential forest characteristics was not attempted by these authors, but they implicitly consider it a palm forest. Another core with pollen data taken in Ranu Raraku (SW) coincides in recording the dominance of palm pollen (Dumont et al., 1998). Unfortunately, the lack of reliable dating and the grouping of all pollen elements other than palms into one single category prevents any further interpretation.

In Rano Kao, the first pollen results (core KAO1) were not conclusive due to dating problems (Butler et al., 2004), but a further core (KAO2) was successfully dated and analyzed for pollen. KAO2 covered practically the whole Holocene, from around $9{ }^{14} \mathrm{C}$ kyr BP onwards (Butler and Flenley, 2001). The situation before the "deforestation” is similar to that of Rano Raraku, with palm pollen commonly above 70\%, and Sophora and Triumfetta as common, yet scarce, components of pollen assemblages. From this evidence, it was concluded that the island was forested during the Holocene (Butler and Flenley, 2001). A more recent study includes new dates, but the inferences concerning forest characteristics are essentially the same (Flenley et al., 2007).

The situation is very different at Rano Aroi. The pollen diagram of core ARO1 is largely dominated by Poaceae (typically 40-80\%), with Asteraceae (Tubuliflorae) and 
ferns as subdominants and Coprosma commonly present. Scirpus was added as a dominant from about the half of the diagram onwards. The pollen of Palmae is usually below $10 \%$, with a few isolated exceptions. This situation persisted during the last $~ 37$

${ }^{14} \mathrm{C}$ kyr BP. The general interpretation was that the palm forests deduced from the Rano Raraku section grew on lowlands with their uppermost limit fluctuating around the Rano Aroi elevation (430 m) (Flenley and King, 1984; Flenley et al., 1991). This limit would have been characterized by shrub communities of one or several unknown Asteraceae (Tubuliflorae) and Coprosma (Azizi and Flenley, 2008). Locally, the Rano Aroi site supported intermittent herbaceous marshes and swamps dominated by Cyperaceae and grasses. A short core from Rano Aroi (Drive 3) was analyzed by Peteet et al. (2003). It was tentatively dated as representing the end of the Pleistocene (14 to 10 ${ }^{14} \mathrm{C}$ kyr BP), and the pollen data are in agreement with the results previously obtained from core ARO1. The big picture for Easter Island's forest evolution since the LGM has been represented by Flenley and Bahn (2003) in a graphical sketch (Fig. 4), where it can be seen that the proposed treeline only existed during the LGM and the late glacial period. After that, the whole island would have been covered by forests until the hypothetical human deforestation beginning around AD 1200 (Mann et al., 2008).

Other pollen and macrofossil evidence is available from archaeological sites. The work of Orliac (2000) is frequently cited in support of the existence of ancient forests covering the island. After analysis of more than 30000 carbonized woody remains from dwelling sites at La Pérouse Bay, Orongo and Ahu Aakhanga (Fig. 1), this author was able to identify more than 20 tree/shrub taxa with ages between 610 and $220 \mathrm{BP}$, half of which are currently absent and also undetected in Pleistocene and Holocene pollen analyses. Due to dating uncertainties, the age of these samples was rounded to represent the period between the beginning of the $14^{\text {th }}$ and the middle of the $17^{\text {th }}$ centuries $\mathrm{AD}$, which, according to Orliac (2000) and Orliac and Orliac (1998), is before the final impoverishment of Easter Island's flora. Some of the taxa identified still live in the island, mostly as relics in the inner Rano Kao crater. These are: Caesalpinia cf. major, Thespesia populnea, Broussonetia papyrifera, Sapindus saponaria and Triumphetta semitriloba. Three other taxa are known only from the above-mentioned pollen analyses: Sophora toromiro, Coprosma and an unknown palm represented by its pollen (a discussion on its identity is provided in the next section). Most of the remaining previously unknown taxa still grow on other Pacific islands (Orliac, 2000). 
Additional archaeological evidence includes pollen, phytolith and starch analyses of samples from Te Niu, Ahu Hekii and la Pérouse, which are dated from around AD 1300 to AD 1850 (Cummings, 1998; Horrocks and Wozniack, 2008). Some of these samples show large amounts of palm remains and have been interpreted as representative of the ancient forests. In the case of Te Niu, four of the five samples containing 40-60\% palm pollen range from AD 1286-1399 (SS199a) to AD 1393-1459 (SS289), and have been interpreted as representative of the pre-deforestation period. The fifth sample (SS299) was dated to AD 1797-1955 (Horrocks and Wozniak, 2008). In these samples, the subdominant shrubs formerly reported in the lake cores are absent, and instead, fern spores are more diverse and abundant. This has been attributed to the particular taphonomic nature of archaeological samples. Phytoliths (mainly of palms) and starch grains from cultivated plants like Dioscorea alata (yam) and Ipomoea batatas (sweet potato) occurred in similar amounts in samples with either high or low palm pollen abundance (Horrocks and Wozniak, 2008). A similar situation was found by Cummings (1998) at the other archaeological sites, but the low number of isolated samples and the lack of dating details prevent a detailed reconstruction.

Edaphic studies have also contributed to paleobotanical reconstruction by providing evidence likely corresponding to palm remains (Flenley, 1993). For example, in Ahu Tongariki, SW of the Poike Peninsula, 29 root casts and carbonized remains of palm trunks and grasses were documented in a $100 \mathrm{~m}$ transect and dated, giving ages between about AD 1300 and AD 1400 (Mieth and Brock, 2003). It was suggested that these features represent a semi-open palm forest, possibly with grasses and some bushes, which was being managed and burnt by humans. Another place with similar but poorer evidence (three root systems) is Maunga Orito, in the SW of the island (Stevenson et al., 2006). Macroscopic fragments of charcoal recovered from colluvial deposits at different island sites (mostly in coastal areas around the major craters, but also a few fragments found more inland on the slopes of Terevaka) showed ages between AD 1220 and AD 1950 (Mann et al., 2008). Some of these fragments were from wood while others have carbon isotopic signature typical of grasses. According to Bork and Mieth (2003) and Mieth and Bork (2010), all these findings taken together suggest that more than $70 \%$ of the island surface was covered by a dense, agriculturally-used palm forest. 


\subsection{Some uncertainties and more possibilities}

The idea of a forested island previous to the assumed human-induced catastrophe is based on the evidence presented above, and it is a widespread belief accepted even by those more skeptical of the potential anthropic disaster (e.g., Hunter-Anderson, 1998). To summarize the currently accepted scenario, the ancient forests were dominated by palms (probably one single species, see discussion below), Sophora toromiro and Truimfetta semitriloba as the main trees, and a shrubby understory. The altitudinal treeline fluctuated around $400 \mathrm{~m}$ in elevation and was characterized by a shrubby zone with several unknown Asteraceae (Tubuliflorae) and Coprosma (Azizi and Flenley, 2008). Here, we discuss some uncertainties of this view and analyze alternative proposals, with the sole aim of eventually finding additional hypotheses consistent with the available evidence.

The first weakness of the prevailing reconstruction is the lack of modern analogs for the assumed ancient forests. As is well known, one of the better approaches for paleoecological reconstruction based on pollen analysis is comparison with modern ecosystems and the pollen assemblages they release and deposit in appropriate sediments (Jackson and Williams, 2004). At present, the vegetation of the island is so disturbed that a study of this type is no longer feasible, but the possibility of modern analogs from elsewhere (other pacific islands? South America?) has not been seriously considered so far. It is also known that many past biotic communities were different from present ones in composition and have no present modern analogs, which complicates their ecological characterization (Jackson and Williams, 2004). This could be the case for Easter Island, but it cannot be confirmed without a careful analysis. The impression obtained from the literature survey carried out for this review is that this point has not been fully exploited and should be encouraged. An interesting point is that pollen assemblages recovered in the sediments of Easter Island lakes and bogs most likely originated from the island and are not derived from long-distance wind transport from other distant sites, like for example South America or other Pacific islands. This has been made apparent by analysis of modern pollen assemblages from the nearby small island of Salas y Gómez (situated $415 \mathrm{~km}$ ENE), where the only pollen found is from its four local vascular plant species (Flenley and Empson, 1996), thus showing that long-distance pollen transport does not occur. This makes Easter Island a good place to 
use dispersal modeling to deduce the characteristics of past pollen sources (i.e., past local vegetation) and their evolution from the pollen content of ancient sediments (Sugita, 2007a, b).

Another point that deserves attention is the occurrence of a potential treeline for the ancient forests. The existence of an upper forest limit around Rano Aroi was deduced from the low abundance of palm pollen throughout the whole diagram as compared to the dominance of this pollen type in lowland lakes (Rano Kao and Rano Raraku) during the late Pleistocene and most of the Holocene. This interpretation emphasizes the altitude as the differential factor between these situations, but there are other important environmental and paleoenvironmental differences. For example, according to the sedimentological interpretation, Rano Kao and Rano Raraku are lakes and have been so for most of the interval studied, while Rano Aroi has been a peat bog throughout this time (Sáez et al. 2009). Therefore, differences in basin size and morphology, as well as in local hydrological conditions (i.e., the existence or not of a permanent water body, the connection or not with the groundwater system, etc.) would have determined the particular microclimatic conditions and the establishment of different plant communities around each of these sites, such as for example a palm-dominated gallery forest around the lakes and a shrubby community around the bog. A gallery forest around a lake, favored by the occurrence of a local subsurficial water table, would be able to provide sufficient pollen to reach the values recorded in Rano Kao and Rano Raraku sediments, and it would obviate the need to postulate a forested island. Furthermore, palm gallery forests are common in tropical and neotropical areas around water bodies such as rivers and lakes (e.g., Henderson et al., 1995). Other sites with evidence for palm communities are on the coasts at Te Niu and Ahu Tongariki (Mieth and Brok, 2003; Horrocks and Wozniak, 2008). Therefore, a coastal palm fringe or a set of isolated palm stands along the coasts, also favored by the proximity of the water table (Fig. 2), are scenarios worthy of consideration. In the absence of modern analog studies of pollen deposition patterns, this hypothesis is as credible as that of a forested island. In support to this, studies on modern pollen sedimentation in crater lakes of similar size and characteristics than those of Easter Island have shown that pollen assemblages reflect local vegetation conditions rather than regional vegetation patterns, especially when lakes are surrounded by gallery forests (Walker, 2000). In addition, the existence of a forest belt around the lakes could have acted as a filter for pollen from other plant formations, thus 
contributing to increase the relative abundance of local forest pollen. If this proposal is favored by further evidence, eventual climatically-driven oscillations in the water table position would determine changes in the position and extent of the assumed gallery and coastal forests. Therefore, changes in the hydrological balance (precipitation/evapotranspiration ratio) such as those suggested by Sáez et al. (2009) over the last 34000 years, and not only human disturbance, would emerge as important forcing factors for vegetation change on Easter Island.

On the other hand, it is known that treeline elevations are controlled by climate and have a clear latitudinal gradient (Körner, 1998). It is also known that treelines are in general lower on oceanic islands than in continental areas at the same latitude (Leuschner, 1996). Easter Island is at $\sim 27^{\circ} \mathrm{S}$, an intermediate latitude between Réunion $\left(21^{\circ} \mathrm{S}\right)$ and Juan Fernández ( $\left.34^{\circ} \mathrm{S}\right)$ islands, where the treelines are situated at 22002400 and 700-750 m respectively (Leuschner, 1996). Therefore, the present corresponding treeline altitude for Easter Island would be around 1400-1600 m. A hypothetical treeline around $400 \mathrm{~m}$, as proposed by Flenley et al. (1991) for the late Pleistocene (including the LGM), involves a 1000-1100 m difference, that using a commonly accepted lapse rate of $-0.55^{\circ} \mathrm{C} / 100 \mathrm{~m}$ altitude, implies a cooling of 5.5-6.0 ${ }^{\circ} \mathrm{C}$ with respect to the present. This is in disagreement with current LGM estimates for Easter Island and other Pacific areas, which are around $2{ }^{\circ} \mathrm{C}$ below the present (Azizi and Flenley, 2008). Therefore, the initial hypothesis of a treeline around $400 \mathrm{~m}$ altitude during the last glaciation is unsupported. Furthermore, according to the reconstruction of Flenley and Bahn (2003), the treeline would have disappeared from Rano Aroi and been replaced by forests after the glaciation (Fig. 4). This is in contradiction with the Rano Aroi pollen diagram and its current interpretation, according to which palm forests never occupied the site (Flenley and King, 1984; Flenley et al., 1991). In summary, the hypothesis of a treeline around Rano Aroi leads to several fundamental contradictions, and a more parsimonious interpretation of the differences observed between the pollen diagrams of the peat sequence from Rano Aroi and the lacustrine sequences from Rano Kao and Rano Raraku would be in terms of local differences in basin size, substrate, climatic and/or hydrological conditions.

The issue of the additional tree and shrub taxa identified in wood fragments from archaeological samples by Orliac (2000) also merits some consideration. The discovery 
of so many potential forest taxa previously undetected in pollen diagrams at three different and widespread localities of the island seems surprising. Factors such as low pollen production and/or dispersion power of the taxa involved could be invoked as a partial explanation. However, the time frame and the context involved are critical factors. First, the evidence is restricted to a few centuries $\left(14^{\text {th }}\right.$ to $\left.17^{\text {th }}\right)$ and is directly associated with quotidian human activities; hence, the identified remains cannot be taken as representative of assumed ancient forests, but rather represent species commonly used by humans at that time. Second, the pollen of these taxa is totally absent, not only in lake and bog sediments, but also in similar anthropological samples containing pollen, which show more or less the same assemblages recorded in sedimentary samples (Cummings, 1998; Horrocks and Wozniak, 2008). Therefore, former arguments related to pollen production or dispersal to explain their absence in pollen diagrams lose strength. It would be interesting to see the results of pollen analysis of Orliac's (2000) samples, as well as of anthracological analyses of wood and charcoal fragments outside human settlements. Third, the time interval considered in the archaeological studies lies within the process of substitution of palm forests by grasslands, and cannot represent the original forests. In summary, the anthracological evidence available so far provides little support for the existence and composition of potential ancient forests. Human activities such as gardening, tree cropping or the use of wood transported from other islands (note the absence of pollen) are not incompatible with the evidence.

It is important to realize that, except for the pollen records, all the other evidence on the composition and characteristics of Easter Island's former forests comes from archaeological sites situated along the coasts, and corresponds to the period between about AD 1200 and AD 1700, when the original vegetation was under intense exploitation. Therefore, the paleobotanical evidence available so far for Easter Island between these dates cannot represent the composition and characteristics of the original forests, but rather represents the vegetation associated with human environments along the coasts. Therefore, palynological data are still the key evidence for the reconstruction of the vegetation prior to human arrival. Taken as a whole, the palynological evidence discussed for Easter Island during the late Pleistocene and most of the Holocene is not incompatible with mosaic vegetation, with palm-dominated gallery forests inside the crater lakes, palm stands on coastal areas intermingled with shrublands and (possibly) 
more restricted herbaceous communities. The occurrence of gallery forests inside the craters would be favored by the existence of a humid microclimate created by the presence of the lakes, a condition that does not occur in any other place on the island, as for example in Rano Aroi, from which paleoecological record does not reflect the presence of palm forests (Flenley and King, 1984; Flenley et al., 1991). The island has the necessary environmental heterogeneity for such a scenario, with differences in (among other things) geology, altitude, topography, soil, exposure to sun and wind, and slope orientation. (McLaughlin, 2007).

\subsection{The identity of the palms}

Since the discovery of palm-like pollen in the Rano Raraku sediments by O. Selling (Heyerdahl and Ferdon, 1961), the identity of its parent plant has remained unknown. The first tentative identification by Selling was Pritchardia, which is a common palm in Pacific islands. Further morphological analyses, including SEM studies (Dransfield et al., 1984), showed more similarity with the pollen of the palm tribe Cocosoideae, which in the Pacific region is represented by the widespread Cocos nucifera (the coconut) and Jubaea chilensis (the wine palm), at present inhabiting the Chilean coasts. The first possibility was initially rejected because the coconut is a typical tropical palm and Easter Island is subtropical, and also because the initial attempts to introduce this palm to the island were unsuccessful (Flenley et al., 1991). The independent discovery of small palm nuts (notably smaller than coconuts) and trunk and root casts similar to those of Jubaea in lava caves and soils of the Poike Peninsula was used by some to defend the second option, and to speculate about the possibility of Jubaea seeds traveling from the Chilean coasts aided by the Humboldt and the Equatorial currents (Grau, 1998, 2001). However, the lack of material suitable for a reliable botanical identification (i.e. flowers or inflorescences), and the manifest environmental differences between Easter Island and the Chilean coasts, are serious constraints for this analogy (Dransfield et al., 1984; Hunter-Anderson, 1998). Based on the nut morphology, of which the empty endocarp was the only part available, the genus Paschalococos was defined, and the nuts were assigned to the new species $P$. disperta (Dransfield et al., 1984). This species has been included in the flora of Easter Island, with the subfossil endocarp as the holotype (Zizka, 1991). Another proposed analog for the Easter Island palms is Juania australis, a palm endemic to the Juan Fernández 
Islands, which are situated about $600 \mathrm{~km}$ off the Chilean coast and have a flora very different from that of the mainland, likely due to their long isolation (Hunter-Anderson (1998). The basis for this analogy is again the endocarp morphological similarity. Most subfossil endocarps found so far show evident signs of rat gnawing and have been dated to between about $800{ }^{14} \mathrm{C}$ years BP to AD 1680 (Flenley, 1993).

To summarize, the identity of the parent plants of the abundant palm pollen recorded at Rano Kao and Rano Raraku sediments still remains a mystery. The discussion has centered on the endocarps, which seems to be the more suitable material available for botanical identification. DNA analyses have not yet been attempted, because it has been assumed that neither the pollen grains nor the endocarp cells contain appropriate cytoplasmic material, and the problem is being approached by detailed anatomical comparisons with Jubaea and related palms (Dransfield, 2008). However, some techniques that have been proven to be useful for recovering and analyzing DNA from subfossil Holocene pollen grains (e.g., Suyama, 1996; Parducci et al., 2005) might be applicable. So far, all the inferences about the identity of the enigmatic Easter Island palm are based on the assumption that the pollen, endocarps, carbonized trunks and root casts belong to the same species, but a necessary link between them has not been properly established yet. The comparison of DNA from the problematic subfossil pollen with that of pollen from a set of selected palm species would be the best way of identifying the parent palm (if still living), or at least of establishing more probable phylogenetic relationships, if already extinct. The identification of the mysterious palm to some taxonomic extent would be very useful to know more on the eventual Easter Island past forests. In general, DNA studies can be of great help to paleoecology (Flenley, 2003). The first attempts at recovering DNA from lake sediments to aid past reconstructions have been very promising (Matisoo-Smith et al., 2008). Another technique that may help is the isotopic analysis of key elements such as carbon, which has demonstrated its utility for distinguishing among different taxa and vegetation types from soil samples, and which has thus helped elucidate historic ecological trends (Pessenda et al., 2001, 206). 


\section{The recent deforestation}

The paleobotanical evidence for the presumed ecological disaster on Easter Island is of two main types: 1) the replacement of palm-dominated by grass-dominated pollen assemblages in the sedimentary record of two lakes (Flenley and King, 1984; Flenley et al., 1991; Butler and Flenley, 2001; Flenley et al., 2007; Mann et al., 2008), and 2) the finding, in some soils and some former dwelling areas, of charcoal derived from several tree and shrub species (including palms) no longer present on the island, sometimes mixed with grass charcoal (Arnold et al., 1998; Orliac and Orliac, 1998; Orliac, 2000; Mieth and Brock, 2003, 2005). According to the current interpretation, both indicate the presence of former forests and their subsequent replacement by the extensive grasslands that today dominate the landscape. Other types of non-botanical evidence for the proposed ecological and cultural collapse are beyond the scope of this paper and are summarized by Flenley et al. (2007). The idea of the collapse is generally accepted, but the main discrepancies regard causes and timing, which are not independent. The causes are still intensively debated (e.g., Hunt and Lipo, 2007; Flenley et al., 2007).

Concerning timing, after many discussions, it is now believed that the deforestation was not sudden but time-transgressive (Cole and Flenley, 2007; Flenley et al., 2007), and dates vary depending on the site considered. According to Flenley et al. (2007), the first evidence for human disturbance of palm forests is a 1900 year-old layer from Rano Kao in which palm pollen suddenly declined and grasses increased, coinciding with a manifest charcoal augmentation suggestive of forest burning. But the decisive, irreversible replacement of palm forests by grasslands seems to have started around AD 1200, as recorded in Rano Raraku through the same palynological signal (Mann et al., 2008). The oldest date that records human disturbance is around the middle of the $17^{\text {th }}$ century, and this is based on macroscopic charcoal fragments derived from the now absent trees and shrubs (Orliac, 2000). Other charcoal fragments and palm endocarps show intermediate ages (Flenley, 1993; Mieth and Bork, 2003; Hunt, 2007; Mann et al., 2008). Therefore, there is a period of nearly 500 years, roughly between AD 1200 and $\mathrm{AD} 1700$, of intense human use and disturbance of the original vegetation.

Accepting the hypothesis of an island with 70\% of its surface covered by forests, and using the spatial patterns of palm trees inferred from their root imprints, Bork and Mieth 
(2003) and Mieth and Bork (2010) estimated that about 16 million of these trees were present on Easter Island prior to the recent deforestation. An intriguing question regards the fate this much carbon, considering the very small quantity of wood and charcoal remains found so far on the island (summary by Mieth and Bork, 2010).

A recurrent difficulty for the study of the most recent history of Easter Island has been the more or less persistent absence of suitable sediments representing the last centuries and millennia. The first cores studied did not recover sediments younger than $2000{ }^{14} \mathrm{C}$ years BP at Rano Aroi, and they showed an interruption in the Rano Raraku sedimentary record around $7000{ }^{14} \mathrm{C}$ years BP and a hiatus between this date and ca. $500{ }^{14} \mathrm{C}$ years BP (Flenley and King, 1984; Flenley et al., 1991). In Rano Kao (KAO2), the existence of dating inversions complicated the picture even more (Butler et al., 2004). As a consequence, the precise date of the palm pollen decline, which occurred in the missing time interval, could not be determined. A more recent core from Rano Raraku improved the situation somewhat by reducing the gap to an interval between about $4000{ }^{14} \mathrm{C}$ years BP and $800{ }^{14} \mathrm{C}$ years BP (AD 1200-1300). The gap has been attributed to intense mid to late Holocene drought phases leading to persistent low water tables, sub-aerial exposure and erosion of sediments (Man et al., 2008, Sáez et al., 2009). This has been useful as it demonstrates that, in this lake, the final decline of palm pollen occurred before AD 1200. In Rano Kao, further dating efforts with KAO2 led to a coherent sequence for the last millennium with a shorter sedimentary gap between about 2000 cal years BP and 500 cal years BP (AD 1500) (Butler and Flenley, 2001; Flenley et al., 2007). In this way, the early human disturbance of the palm forest that occurred around $1900 \mathrm{cal}$ years BP, its subsequent recovery at ca. 500 cal years BP, and the final decline after this date, were recorded (Flenley et al., 2007). An additional core obtained at Rano Kao (KAO05-3A) covers the entire Holocene with only a minor hiatus between $1200{ }^{14} \mathrm{C}$ years BP and $600{ }^{14} \mathrm{C}$ years BP (Gossen, 2007). A set of paleoecological and paleoclimatic analyses are in progress at present with this core. A solution is beginning to emerge for one of the Easter Island's enigmas (Flenley and Bahn, 2003). 


\section{Final remarks and possible future studies}

The purpose of this review has not been to refute the idea of a forested island, but to show that this is not the only hypothesis compatible with the available evidence. Our strategy was to establish the facts first and then look for an explanation, as the merging of factual and explanatory elements can lead to circular reasoning. In this review, the first part has been accomplished. After discussion of the evidence, we believe that the forested island hypothesis has not yet been fully established and remains as one reasonable hypothesis among others to be tested with future studies. The only locations where recent (local) deforestation is well supported are the Rano Kao and Rano Raraku craters. As a consequence, speculations about the eventual deforestation's causes are still premature and should wait for a more definite assessment regarding Easter Island's original vegetation.

The tone that the Easter Island debate has acquired recently (e.g., Flenley et al., 2007; Hunt and Lipo, 2007) suggests that the explanatory capacity of the available evidence has been exhausted and that new evidence is needed for more conclusive statements. So far, efforts have been concentrated on the causes and consequences of the recent “ecological disaster," likely because this is more attractive from a human point of view, and not only scientific but also philosophical and socio-political consequences can be derived. This has obscured many other equally interesting aspects such as detailed paleoclimatological reconstructions (ENSO, etc.) and the response of natural systems to environmental changes in such a unique place on Earth. As an isolated and small piece of land, Easter Island is a natural laboratory whose lakes and bogs are a gift for those interested in paleoecology and paleoclimatology. Fortunately, new sedimentary sequences have been obtained during recent years that will hopefully contribute to more sound conclusions (Gossen, 2007; Azizi and Flenley, 2008; Mann et al., 2008; Sáez et al., 2009). Several lines of research have been suggested throughout this paper, some of which should be prioritized.

First, it is important to compare the pollen records with similar situations from oceanic islands where modern analogs are available. The impossibility of having modern analogs for Easter Island's past vegetation -a not unusual problem in paleoecology (Jackson and Williams, 2004)- would be palliated with studies from elsewhere that are 
reasonably comparable. The key question is whether known palm-dominated forests can be characterized with studies of modern sedimentation and differentiated from the local pollen signal of more reduced palm stands or from mosaic vegetation. Models can also help in this task by attempting to reconstruct pollen sources from sedimentary assemblages and climatological parameters with emphasis on wind direction and intensity. Second, to obtain accurate and reliable paleoecological reconstructions of the Pleistocene and Holocene, it will be essential to develop high-resolution multi-proxy studies of the available sequences. The detailed analysis of sediments from pre-human times is crucial for elucidating whether climate changes or other environmental forcing factors have been important for Easter Island's ecological history. It would be also interesting to obtain deeper sediments that can provide longer reconstructions, as these could reveal the consequences of glacial-interglacial alternation. The Rano Aroi swamp, in spite of its presumed higher paleoclimatic sensitivity (Hunter-Anderson, 1998), has been less studied than the two lakes, probably because Flenley et al. (1991) presumed that its upper layers -likely containing the deforestation record- have been recently disturbed. However, this seems to be a key site, and the search for new suitable coring locations in this bog is a worthy pursuit.

The issue of DNA analysis is not closed, and the search for suitable materials should not be stopped. Furthermore, it is expected that recent and future technical developments will enhance the possibility of applying these methodologies. The isotopic composition of charcoal and organic remains would help to identify the original vegetation from which these fragments derive, and would shed light on the composition and abundance of former vegetation patterns. Finally, the possibility of seismic surveys and coring campaigns in the surrounding marine sediments should be considered, under the hypothesis that the deforestation indeed occurred and most of the missing organic matter budget lies outside the island. In this case, the combined use of pollen, DNA and isotopic analyses would be especially useful to deduce the provenance of the sedimentary organic matter. Given the narrowness of the shelf around the island (Fig. 1) and the fact that it is constantly beaten by waves, it is unlikely that suitable sediments would be found in it, so the prospective sites would be at deeper locations. 


\section{Acknowledgments}

Funding has been provided by the Spanish Ministry of Science and Innovation through the project GEOBILA (CGL2007-60932/BTE). We are grateful to the Chilean forestry agency (CONAF) for official permits and field facilities, and to the Riroroko family for accommodation facilities at Hanga Roa and help during the fieldwork. 


\section{References}

Arnold, M., Orliac, M., Valladas, H., 1990. Donées nouvelles sur la disparition du palmier (cf. Jubaea) de l'Ile de Pâques. Courier Forschungsinstitut Senckenberg 125, 217-219.

Azizi, G., Flenley, J.R., 2008. The last glacial maximum climatic conditions on Easter Island. Quaternary International, 184, 166-176.

Bork, H.R., Mieth, A., 2003. The key role of Jubaea palm trees in the history of Rapa Nui, a provocative interpretation. Rapa Nui Journal 17, 119-121.

Butler, K., Flenley, J. R., 2001. Further pollen evidence from Easter Island. In: Stevenson, C.M., Lee, G., Morin, F.J. (Eds.), Pacific 2000, Proceedings of the Fifth International Conference on Easter Island and the Pacific. Kamuela, Hawaii, pp. 79-86.

Butler, K., Prior, C.A., Flenley, J. R., 2004. Anomalous radiocarbon dates from Easter Island. Radiocarbon 46, 395-405.

Carlquist, S., 1967. The biota of long-distance dispersal V. Plant dispersal to Pacific islands. Bulletin of the Torrey Botanical Club 44, 129-162.

Carlquist, S., 1974. Island biology. Columbia University Press, New York, 660 pp.

Cole, A., Flenley, J., 2007. Human settlement of Easter Island - a competing hypothesis. Earth and Environmental Science Transactions of the Royal Society of Edinburgh 98, 101-116.

Cummings, L. S., 1998. A review of recent pollen and phytolith studies from various contexts on Easter Island. In: Stevenson, C.M., Lee, G., Morin, F.J. (Eds.), Easter Island in Pacific context, South Seas Symposium. Proceedings of the Fourth International Conference on Easter Island and East Polynesia, Alburquerque, USA, pp. 100-106. 
Diamond, J., 2005. Collapse. How societies choose to fail or survive. Allen Lane, London, 592 pp.

Dransfield, J., 2008. Excerpts from the IPS Palm Talk.

www.pacsoa.org.au/pamls/Paschalococos/disperta.html (last visit June 25, 2009).

Dransfield, J., Flenley, J.R., King, S.M., Harkness, D.D., Rapu, S., 1984. A recently extinct palmfrom Easter Island. Nature 312, 750-752.

Dumont, H.J., Cocquyt, C., Fontugne, M., Arnold, M., Reyss, J.L., Bloemendal, J., Oldfield, F., Steenbergen, L.M., Korthals, H.J., Zeeb, B., 1998. The end of moai quarrying and its effects on Lake Rano Raraku, Easter Island. Journal of Paleolimnology 20, 409-422.

Etienne, M., Michea, G., Díaz, E., 1982. Flora, vegetación y potencial pastoral de la Isla de Pascua. Boletín Técnico n 47, Universidad de Chile, Facultad de Ciencias Agrarias, Veterinarias y Forestales, Santiago.

Flenley, J.R., 1993. The palaeoecology of easter Island, and its ecological disaster. In Fischer, S.R. (Ed.), Easter Island studies. Contribution to the history of Rapa Nui in memory of T. Mulloy. The Short Run Press, Exeter, pp. 27-45.

Flenley, J. R., 2003. Some prospects for lake sediment analysis in the $21^{\text {st }}$ century. Quaternary International, 105, 77-80.

Flenley, J.R., Bahn, P. G., 2003. The enigmas of Easter Island. Oxford University Press, Oxford, 256 pp.

Flenley, J. R., Bahn, P. G., 2007a. Conflicting views of Easter Island. Rapa Nui Journal $21,11-13$.

Flenley, J.R., Bahn, P. G., 2007b. Ratted out. American Scientist 95, 4-5. 
Flenley, J.R., Empson, L.K., 1996. Salas y Gómez, a natural pollen trap in the Pacific and its significance for the interpretation of island pollen diagrams. Rapa Nui Journal $10,17-20$.

Flenley, J.R., King, S., 1984. Late Quaternary pollen records from Easter Island. Nature 307, 47-50.

Flenley, J.R., Butler, K., Bahn, P.G., 2007. Respect versus contempt for evidence, reply to Hunt and Lipo. Rapa Nui Journal 21, 98-104.

Flenley, J.R., King, A.S.M., Jackson, J., Chew, C., 1991. The Late Quaternary vegetational and climatic history of Easter Island. Journal of Quaternary Science 6, 85115.

Genz, J., Hunt, T.L., 2003. El Niño/Southern Oscillations and Rapa Nui prehistory. Rapa Nui Journal 17, 7-14.

Gossen, C., 2007. The mystery lies in the Scirpus. Rapa Nui Journal 21, 105-110.

Grau, J., 1998. The Jubaea palm, key in the transportation of Moai on Easter Island. In: Stevenson, C.M., Lee, G., Morin, F.J. (Eds.), Easter Island in Pacific context, South Seas Symposium. Proceedings of the Fourth International Conference on Easter Island and East Polynesia, Alburquerque, USA, pp. 120-124.

Grau, J., 2001. More about Jubaea chilensis on Easter Island. In: Stevenson, C.M., Lee, G., Morin, F.J. (Eds.), Pacific 2000, Proceedings of the Fifth International Conference on Easter Island and the Pacific. Kamuela, Hawaii, pp. 87-90.

Gurley, R.E., Liller, W., 1997. Palm trees, Mana, and the moving of moais. Rapa Nui Journal 11, 82-84.

Henderson, A., Galdeano, G., Bernal, R., 1995. Field guide to the palms of the Americas. Princeton University Press, Princeton, 352 pp. 
Herrera, C., Custodio, E., 2008. Conceptual hydrogeological model of volcanic Easter Island (Chile) after chemical and isotopic surveys. Hydrogeology Journal 16, 13291348.

Heyerdahl, T., Ferdon, E. N., 1961. Reports of the Norwegian archaeological expedition to Easter Island and the East Pacific. Vol. 1, Archaeology of Easter Island. Forum Publishing House, Stokholm.

Horrocks, M., Wozniak, J. A., 2008. Plant microfossil analysis reveals distrubed forest and mixed-crop, dryland production system at Te Niu, Easter Island. Journal of Archaeological Science 35, 126-142.

Hunt, T. L., 2006. Rethinking the fall of Easter Island. American Scientist, 94, 412-419.

Hunt, T. L., 2007. Rethinking Easter Island's ecological catastrophe. Journal of Archaeological Science 34, 485-502.

Hunt, T. L., Lipo, C. P., 2006. Late colonization of Easter Island. Science, 311, 16031606.

Hunt, T. L., Lipo, C. P., 2007. Chronology, deforestation, and “collapse”, evidence vs. faith in Rapa Nui prehistory. Rapa Nui Journal 21, 85-97.

Hunter-Anderson, R.L., 1998. Human vs. climatic impacts at Rapa Nui, Did people really cut down all those trees? In: Stevenson, C.M., Lee, G., Morin, F. J. (Eds.), Easter Island in Pacific context, South Seas Symposium. Proceedings of the Fourth International Conference on Easter Island and East Polynesia, Alburquerque, USA pp. 95-99.

Jackson, S.T., Williams, J.W., 2004. Modern analogs in Quaternary paleoecology, Here today, gone yesterday, gone tomorrow? Annual Reviews of Earth and Planetary Sciences 32, 495-537. 
Körner, C., 1998. A re-assessment of high elevation treeline positions and their explanation. Oecologia 115, 445-459.

Landaeta, M.F., Neira, F.J. Castro, L. R., 2003. Larvae of Dactylopsaron dimorphicum (Perciformes, Percophidae) from oceanic islands in the southeast Pacific. Fish Bulletin 101, 693-697.

Leuschner, C., 1996. Timberline and alpine vegetation on the tropical and warmtemperate oceanic islands of the world, elevation, structure and floristics. Vegetatio 123, 193-206.

Louwagie, G., Stevenson, C.M., Langohr, R., 2006. The impact of moderate to marginal land suitability on prehistoric agricultural production and models of adaptive strategies for Easter Island (Rapa Nui, Chile). Journal of Anthropological Archaeology 25, 290317.

MacIntyre, F., 2001. ENSO, climate variability, and the Rapanui, part II. Oceanography and Rapa Nui. Rapa Nui Journal 15, 83-94.

Mann, D., Edwards, J., Chase, J., Beck, W., Reanier, R., Mass, M., Finney, B., Loret, J., 2008. Drought, vegetation change, and human history on Rapa Nui (Isla de Pascua, Easter Island). Quaternary Research 69, 16-28.

Matisoo-Smith, E., Roberts, K., Welikala, N., Tannock, G., Chester, P., Feek, D., Flenley, J.R., 2008. Recovery of DNA and pollen from New Zealand lake sediments. Quaternary International 184, 139-149.

Maunder, M., Culham, A., Alden, B., Zizka, G., Orliac, C., Lobin, W., Bordeu, A., Ramírez, J.M. and Glissmann-Gough, S., 2000. Conservation of the Toromiro tree, case study in the management of a plant extinct in the wild. Conservation Biology 14, 13411350.

McCall, G., 1993. Little Ice Age, some speculations for Rapanui. Rapa Nui Journal 7, 65-70. 
McLaughlin, S., 2007. The complete guide to Easter Island. Easter Island Foundation, Los Osos, 350 pp.

Mieth, A., Bork, H.R., 2003. Diminution and degradation of environmental resources by prehistoric land use on Poike Peninsula, Easter Island (Rapa Nui). Rapa Nui Journal 17, 34-41.

Mieth, A., Bork, H.R., 2005. History, origin and extent of soil erosion on Easter Island (Rapa Nui). Catena 63, 244-260.

Mieth, A., Bork, H.R., 2010. Humans, climate or introduced rats - which is to blame for the woodland destruction of prehistoric Rapa Nui (Easter Island)? Journal of archaeological Science 37, 417-426.

Muccianore, D., Dunbar, R., 2003. Stable isotope record of El Niño - Southern Oscillation events from Easter Island. In: Loret, J., Tanacredi, J. T. (Eds.), Easter Island. Scientific exploration into the world's environmental problems in microcosm. KluwerAcademic/Plenum Publ., New York, USA, pp. 113-132.

Mujica, A., 2006. Larvas de crustáceos decápodos y crustáceos holoplanctónicos en torno a la Isla de Pascua. Ciencia y Tecnología del Mar 29, 123-135.

Nagarajan, P., 2006. Collapse of Easter Island. Lessons for sustainability of small islands. Journal of Developing Societies 22, 287-301.

Nunn, P. D., 2000. Environmental catastrophe in the Pacific islands around A.D. 1300. Geoarchaeology 15, 715-740.

Nunn, P. D. and Britton, J. M. R., 2001. Human-environment relationships in the Pacific islands around A.D. 1300. Environment and History 7, 3-22.

Parducci, L., Suyama, Y., Lascoux, M., Bennett, K.D., 2005. Ancient DNA from pollen, a genetic record of population history in Scots pine. Molecular Ecology 14, 2873-2882. 
Orliac, C., 2000. The woody vegetation of Easter Island between the early $14^{\text {th }}$ and the mid-17 $7^{\text {th }}$ centuries AD. In: Stevenson, C.M., Ayres, W.S. (Eds.), Easter Island archaeology. Research on early Rapanui Culture. Easter Island Foundation, Los Osos, pp. 211-220.

Orliac, C., Orliac, M., 1998. The disappearance of Easter Island’s forest, overexploitation or climatic catastrophe? In: Stevenson, C.M., Lee, G., Morin, F.J. (Eds.), Easter Island in Pacific context, South Seas Symposium. Proceedings of the Forth International Conference on Easter Island and East Polynesia, Alburquerque, USA, pp. 129-134.

Peiser, B., 2005. From genocide to ecocide, the rape of Rapa Nui. Energy and Environment 16, 513-539.

Pessenda, L.C.R., Boulet, R., Aravena, R., Rosolen, V., Gouveia, S.E.M., Ribeiro, A.S., Lamotte, M., 2001. Origin and dynamics of soil organic matter and vegetation changes during the Holocene in a forest-savanna transition zone, Brazilian Amazon region. The Holocene 11, 250-254.

Pessenda, L.C.R., Ribeiro, A., Gouveia, S.E., Aravena, R., Boulet, R., Bendassolli, A., 2004. Vegetation dynamics during the late Pleistocene in the barreirinhas region, Maranhao State, northeastern Brazil, based on carbon isotopes in soil organic matter. Quaternary Research 62, 183-193.

Peteet, D., Beck, W., Ortiz, J., O’Connell, S., Kurdyla, D., Mann, D., 2003. Rapid vegetational and sediment change from Rano Aroi crater, Easter Island. In: Loret, J., Tanacredi, J.T. (Eds.), Easter Island. Scientific exploration into the world’s environmental problems in microcosm. Kluwer Academic/Plenum Publ., New York, pp. 81-92.

Rainbird, P., 2002. A message for our future? The Rapa Nui (Easter Island) ecodisaster and Pacific island environments. World Archaeology 33, 436-451. 
Sáez, A., Valero-Garcés, B., Giralt, S., Moreno, A., Bao, R., Pueyo, J. J., Hernández, A., Casas, D., 2009. Glacial to Holocene climate changes in the SE Pacific. The Raraku Lake sedimentary record (Easter Island, $27^{\circ}$ S). Quaternary Science Reviews 28, 27432759.

Stevenson, C.M., Jackson, T.J., Mieth, A., Bork, H.R., Ladefoged, T. N., 2006.

Prehistoric and early historic agriculture at Maunga Orito, Easter Island (Rapa Nui), Chile. Antiquity 80, 919-936.

Sugita, S., 2007a. Theory of quantitative reconstruction of vegetation I, pollen from large sites REVEALS regional vegetation composition. The Holocene 17, 229-241.

Sugita, S., 2007b. Theory of quantitative reconstruction of vegetation II, all you need is LOVE. The Holocene 17, 243-257.

Suyama, Y., Kawamuro, K., Kinoshita, I., Yoshimura, K., Tsumura, Y., Takahara, H., 1996. DNA sequence from a fossil pollen of Abies spp. from Pleistocene peat. Genes and Genetic Systems 71, 145-149.

Vargas, P., Cristino, C., Izaurieta, R., 2006. 1000 años en Rapa Nui. Arqueología del asentamiento. Ed. Universitaria, Santiago.

Walker, D., 2000. Pollen input to, and incorporation in, two crater lakes in tropical northeast Australia. Review of Palaeobotany and Palynology 111, 253-283.

Zizka, G., 1991. Flowering plants of Easter Island. Palmarum Hortus Francofurtensis Scientific Reports 3, 1-108.

Zizka, G., 1993. Rapanui flora, needs and possibilities for conservation. In Fischer, S. R. (ed.), Easter Island studies. Contribution to the history of Rapa Nui in memory of T. Mulloy. The Short Run Press, Exeter, pp. 46-49. 


\section{Figure captions}

1. Map of Easter Island with the localities discussed in the text represented as black diamonds. Present-day (planted) forests, mainly of Eucalyptus, are indicated by darkgrey areas. The approximate extension of the shelf is also indicated by the $-100 \mathrm{~m}$ dotted curve (after Landaeta et al., 2003; Mujica, 2006).

2. Schematic cross-section of a N-S transect showing the inferred groundwater system under the middle altitude volcanic core (in black) hypothesis. The other hypotheses (namely "low altitude core" and "high altitude core," respectively) maintain the same morphology for the coastal freshwater wedges. The approximate altitude of the Rano Raraku (RR) and Rano Kao (RK) lakes is indicated by solid horizontal lines. Modified from Herrera \& Custodio (2008).

3. Pictures of the three volcanic craters with continuous cores used for pollen analysis. A) Rano Aroi, B) Rano Kao and C) Rano Raraku (photos by V. Rull).

4. Sketch of Easter Island's landscape evolution since the late glacial period to the present, according to the current interpretation of pollen diagrams from Rano Kao, Rano Raraku and Rano Aroi (Flenley \& King, 1984; Flenley et al., 1991). Redrawn from Flenley \& Bahn (2003). 


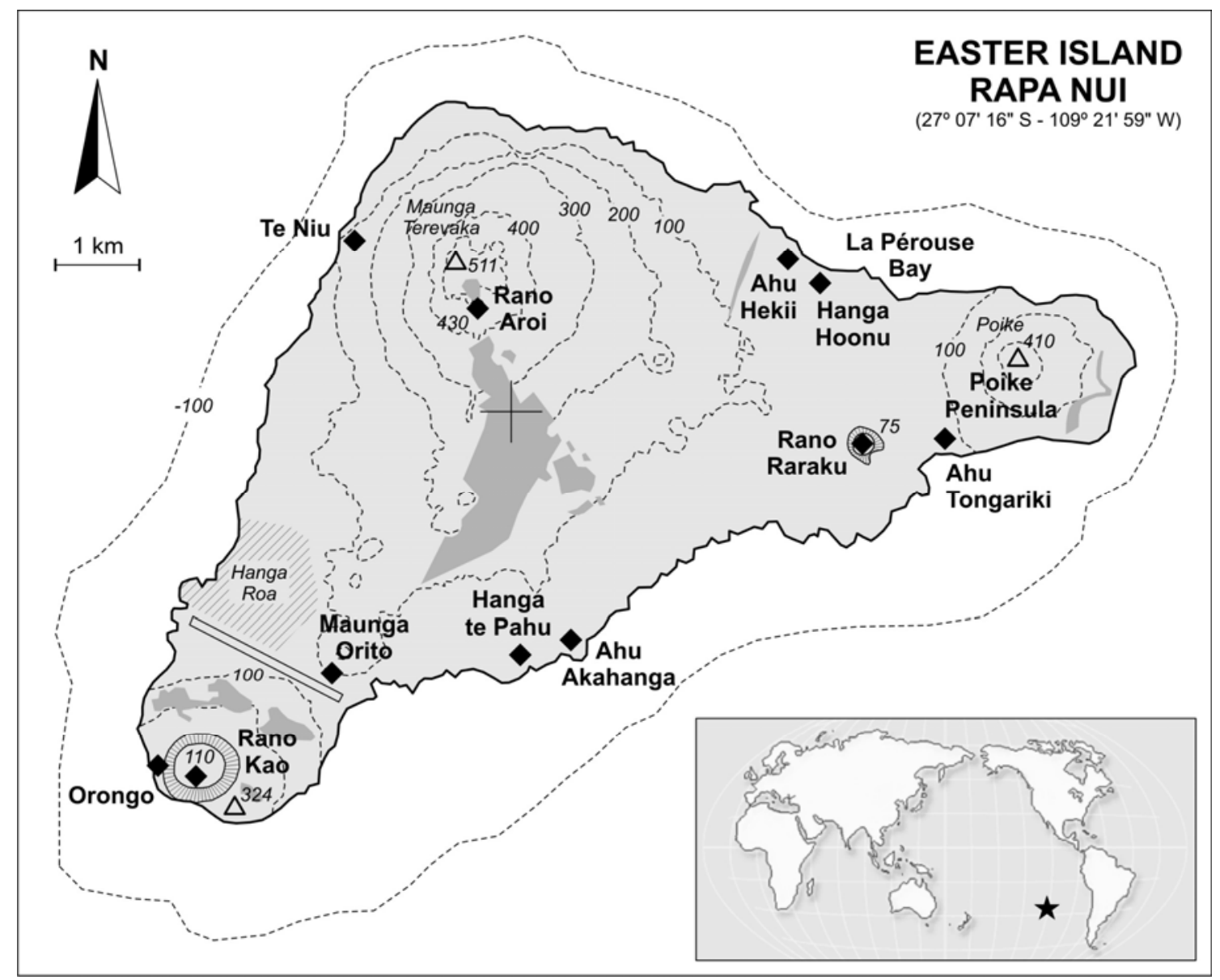

Figure 1 


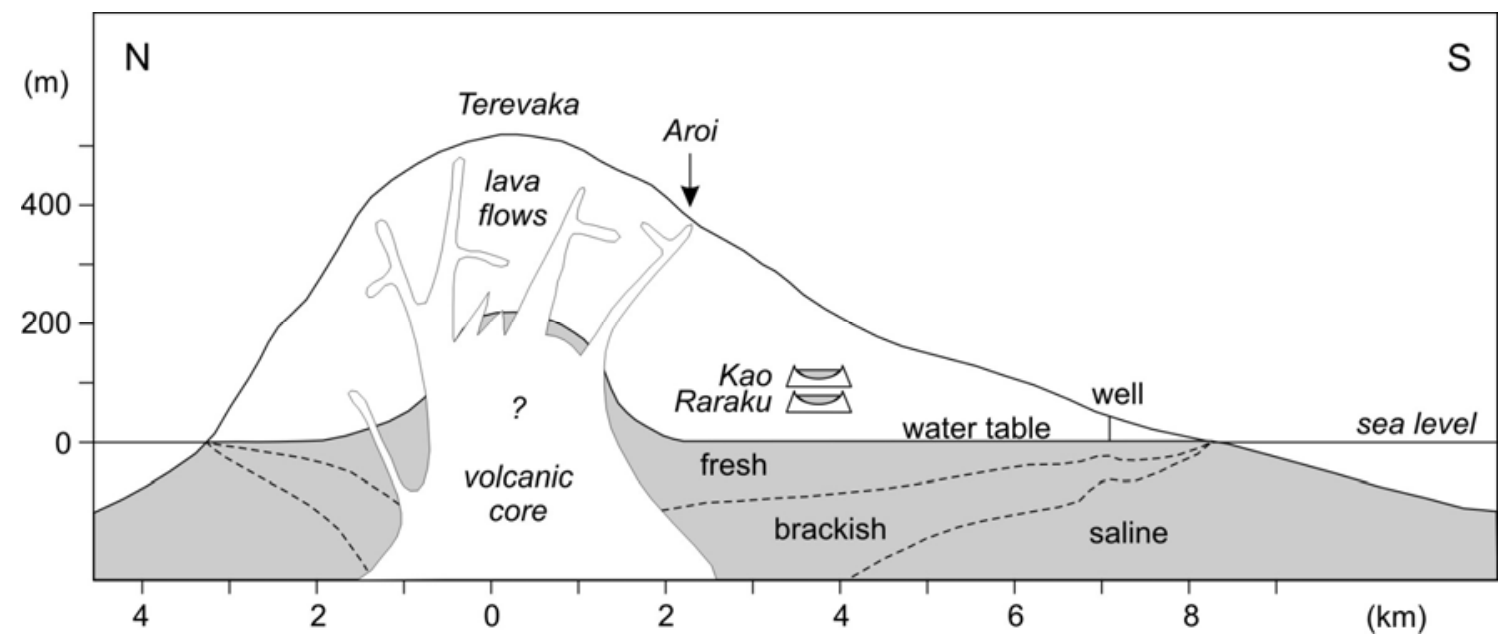

Figure 2 

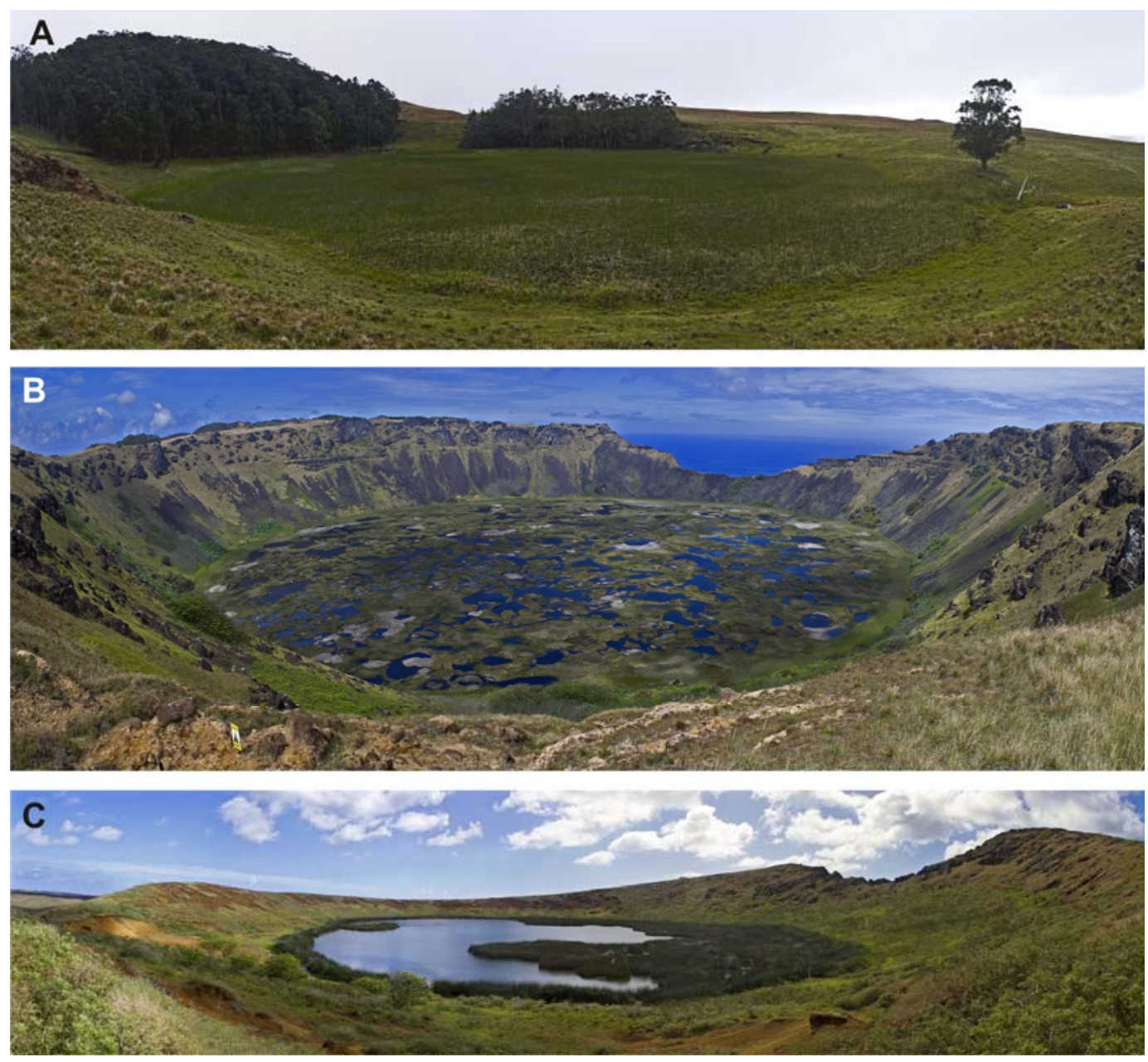

Figure 3 


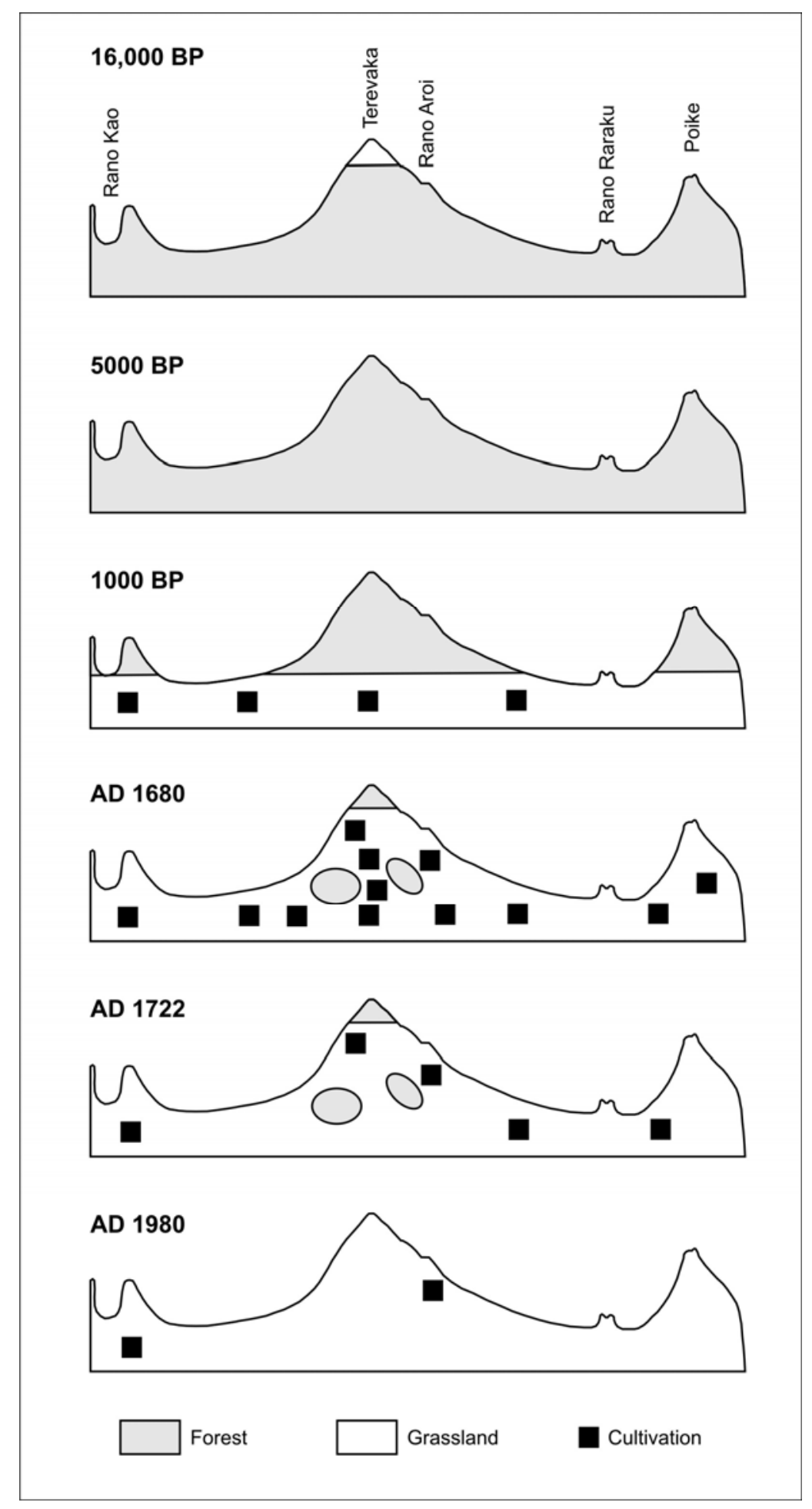

Figure 4 